Proc. Estonian Acad. Sci. Geol., 1996, 45, 3, 149-164

\title{
PREHISTORIC HUMAN DISTURBANCE OF THE ENVIRONMENT INDUCED FROM ESTONIAN POLLEN RECORDS. A PILOT STUDY
}

\author{
Anneli POSKA and Leili SAARSE
}

Geoloogia Instituut (Institute of Geology), Estonia pst. 7, EE-0001 Tallinn, Eesti (Estonia)

Presented by A. Raukas

Received 4 March 1996, accepted 3 June 1996

\begin{abstract}
Thirty pollen diagrams from Estonia were examined and 23 diagrams were selected in order to find indications of the human impact on the environment. The pollen records show the same Stone Age habitation centres as proposed by archaeologists. They form two belts: one on the North Estonian coast and Saaremaa Island, and the other in central Estonia along the valleys of the Pärnu, Suur Emajõgi, and Navesti rivers and on the northern shore of Lake Võrtsjärv. Prehistoric human activities had a rather pulsatory character. The first traces date to about $9500 \mathrm{yr}$ BP and were identified as woodland disturbances on the Baltic Sea coastal area. Later there followed the second forest disturbance phase traceable in North Estonia and Võrtsjärv Lowland (7000-6500 yr BP), also on Saaremaa Island and East Estonia (6500-6000 yr BP). About 5000-4500 yr BP human impact increased notably almost all over Estonia. For 3800 yr BP pollen spectra of several diagrams indicate increasing forest clearance and in some cases also tillage. Indications of extensive forest clearances and crop growing were recorded at about 500 years later $(3300-3200 \mathrm{yr}$ BP) in North Estonia, Võrtsjärv Lowland, and on Saaremaa Island. The first finds of Secale cereale pollen are known already from $2500 \mathrm{yr} \mathrm{BP}$, but obviously at that time rye was growing as a weed in other crop fields. The real introduction of Secale cereale is likely to have started about $1400-1500 \mathrm{yr}$ BP.
\end{abstract}

Key words: tillage, human impact, pollen records.

\section{INTRODUCTION}

The present study is a part of the multidisciplinary project "Environmental History of the Baltic Region" initiated by Prof. U. Miller in the framework of PACT (Physical, Chemical, Biological, and Mathematical Techniques Applied to Archaeology). Within the above 
project the authors were asked to give an overview of the history of colonization and land-use based on pollen records. Biostratigraphical studies have proved useful for such purposes elsewhere (Berglund, 1985, 1991; Behre, 1981, 1988; Hicks, 1990).

Tracing of human activities during Mesolithic and Neolithic time with a biostratigraphical method is a complicated task. The development of woodlands during that period was controlled by climatic, edaphic, and other ecological factors rather than by human activities. Nevertheless, the Stone Age people, whose economy was mainly based on hunting, fishing, and gathering, also utilized the environment around habitation sites, in this way causing forest disturbances and introducing favourable conditions for flourishing and spread of light-demanding and nitrophilous herb species (Behre, 1988). The first traces of primitive farming in Estonia come from Neolithic time. Cattle rearing and crop cultivation were properly introduced during the Bronze Age (Lõugas, 1992). With the advancing of agriculture, man's influence upon the environment increased markedly.

The multidisciplinary study of the human impact was recently undertaken by palaeoecologists and archaeologists in the framework of the PACT Project (Saarse \& Königsson, 1992; Veski \& Lang, 1996; Hackens et al., 1996). Since the coastal area is supposed to be a cradle of farming, it was chosen as a site for describing the development of the early agriculture. As a result, at Maardu and Saha-Loo fossil field remains were found and excavated (Lang, 1996a, b).

Thirty pollen diagrams were examined and 23 diagrams were selected in order to find indications of human impact on the environment (Figure). The material investigated covers almost entire Estonia and different landscape regions, and the time span from the beginning of the Mesolithic until historical time. Most of the sequences analysed are radiocarbon dated. The timescale of five undated sequences (Kunda, Vedruka, Tõhela, Surusoo, and Pitkasoo) is based on the correlation with nearby locations studied. All periods discussed were distinguished according to uncorrected conventional radiocarbon ages.

\section{METHODS}

For the selected sites, the human impact diagrams were reconstructed following the approach of Behre (1981), Berglund \& Ralska-Jasiewiczowa (1986), and Hicks (1990), according to which the plants expected to be connected with the human activities are differentiated into the following groups:

(1) cultivated land (Cerealia, Secale, Triticum, Triticum spelta t., Hordeum, Avena, Cannabaceae, Cannabis t., Centaurea cyanus, Fagopyrum, Polygonum convolvulus); 


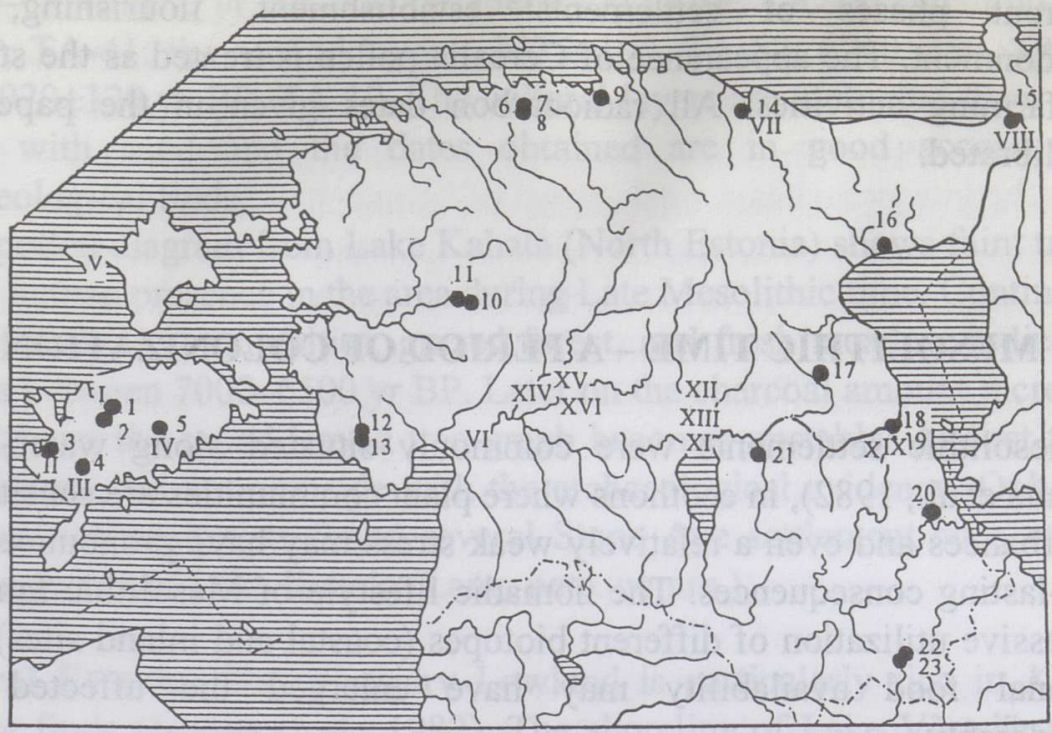

Location of biostratigraphical and archaeological sites mentioned in the text. Biostratigraphical sites: 1, Surusoo (Veski, 1996a); 2, Tuiu (Jõhvikasoo, Hansson et al., 1996); 3, Vedruka; 4, Pitkasoo (Saarse \& Königsson, 1992); 5, Kaali (Saarse et al., 1991); 6, Tondi (Kimmel et al., 1996); 7, Maardu (Veski, 1992, 1996b); 8, Saha (Veski, unpubl.); 9, Kahala (Poska, unpubl.); 10, Kiilaspere (Veski, unpubl.); 11, Velise (Veski, unpubl.); 12, Tõhela (Veski, unpubl.); 13, Ermistu (Veski, unpubl.); 14, Kunda Arusoo (Poska, 1994); 15, Leekovo (Lepland et al., 1996); 16, Võhma (Kimmel, 1994); 17, Raigastvere (Pirrus et al., 1987); 18, Akali (Moora et al., 1988); 19, Saviku (Sarv \& Ilves, 1975); 20, Kalsa (Kimmel, 1994); 21, Ulila (Ilves \& Sarv, 1970); 22, Vaskna (Ilves \& Mäemets, 1987); 23, Tuuljärv (Ilves \& Mäemets, 1987). Archaeological sites (Jaanits et al., 1982): I, Võhma; II, Loona; III, Naakamäe; IV, Kõnnu; V, Kõpu; VI, Pulli; VII, Kunda; VIII, Narva; IX, Akali; X, Kullamäe; XI, Moksi; XII, Umbusi; XIII, Siimusaare; XIV, Lepakose; XV, Tamme; XVI, Jälevere.

(2) fresh meadows (Ranunculaceae, Ranunculus acris t., Plantago sp., Plantago lanceolata, $P . \mathrm{m} / \mathrm{m}$ t., P. maritima, Potentilla, Cerastium, Achillea t., Saussurea t., Solidago t., Cirsium t., Caryophyllaceae, Trifolium, Linum catharticum, Rhinanthus t., Centaurea scabiosa, C. jacea, Scrophulariaceae, Helianthemum, Succisa t., Alchemilla t., Hypericum t., Gypsophila muralis, Vicia cracca, Valeriana);

(3) ruderal communities (Artemisia, Chenopodiaceae, Chenopodium album, Brassicaceae, Urtica, Plantago $\mathrm{m} / \mathrm{m}$ t., Onagraceae, Chamaenerion, Polygonaceae, Polygonum aviculare, P. persicaria, Rumex aclac t., R. acetosella, Centaurea sp., C. nigra, Malvaceae);

(4) grazed forest (Pteridium, Melampyrum);

(5) dry pastures (Juniperus, Cerastium t., Campanula).

Conclusions about forest disturbances are based on abrupt changes in tree pollen curves, finds of light-demanding nonarboreal (NAP) taxa, an increase in charcoal dust, and a general rise in anthropogenic indicators graphs. A fluctuating character of these indications is considered to show 
different phases of settlements: establishment, flourishing, and abandonment. The appearance of Cerealia pollen is treated as the start of the farming activities. All radiocarbon dates given in the paper are uncalibrated.

\section{MESOLITHIC TIME - A PERIOD OF COLONIZATION}

Mesolithic settlements were commonly situated along water-edges (Jaanits et al., 1982), in ecothons where plant communities are sensitive to disturbances and even a relatively weak stress may have pronounced and long-lasting consequences. The nomadic lifestyle of Mesolithic families, successive utilization of different biotopes (coastal and inland sites) after seasonal food availability may have enlarged the affected area considerably.

The first traces of human habitation in Estonia come from the Pulli camp-site near the present Pulli village on the Pärnu River bank (southwestern Estonia; Figure) and are dated to $9600 \pm 120$ (TA-245) and $9575 \pm 115$ yr BP (TA-176; Kessel \& Punning, 1969). This oldest campsite discovered represents the Kunda culture, rather well known from an ancient camp-site on the Kunda Lammasmägi Hill (northern Estonia). The Kunda culture appeared somewhat later and gave the name to the Mesolithic culture (9500-6000 yr BP; Kriiska, 1996a) in Estonia. Archaeological excavations at Kunda were carried out in 1886 (C. Grewingk), 1933-1937 (R. Indreko), 1949, 1961 (L. Jaanits), 1981 (T. Moora and K. Jaanits). According to the pollen record from Kunda Arusoo, two phases of possible man-made Mesolithic forest disturbance have been distinguished (Poska, 1994). A sharp decrease in arboreal (AP) pollen, the appearance of the indicators of fresh meadow and ruderal communities, and abundant charcoal dust refer to the opening up of the area to the beginning of the Boreal or to the Pre-Boreal/Boreal transition. During the second phase, in the Late Atlantic, the amount of the charcoal dust increased and the pollen of the ruderal taxa and forest grazing indicators appeared, showing the forest disturbance at the site and in its surroundings (Poska \& Königsson, 1996).

North and Northeast Estonia. In the Narva area some net remains, found by Indreko (1932) in the former sea bottom at Siiversti, were dated biostratigraphically back to the Boreal/Atlantic boundary (Jaanits et al., 1982), thus being the oldest in North Europe (Kriiska, 1996c). In the Narva Joaoru settlement site (Figure), excavated by L. Jaanits, three Mesolithic strata were distinguished (Jaanits et al., 1982). Cultural layers (charcoal from Joaoru) were dated as follows (Ilves at al., 1974): the first 
layer $-7640 \pm 180$ yr BP, TA-53; $7580 \pm 300 \mathrm{yr} \mathrm{BP}, \mathrm{TA}-25$, and $7090 \pm 230$ yr BP, TA-41; the second layer - 7375 \pm 190 , TA-52; 6740 \pm 250 , TA-40, and $6020 \pm 120 \mathrm{yr}$ BP, TA-17. The cultural layers are separated from each other with sand and the dates obtained are in good accord with archaeological finds.

A pollen diagram from Lake Kahala (North Estonia) shows faint traces of the human presence in the area during Late Mesolithic time. Continuous rise of ruderal communities, grazed forest, and fresh meadow indicators occurs between 7000-6500 yr BP. Later on the charcoal amount increases sharply and the broad-leaved tree graph becomes unstable. At first these conclusions did not coincide with the archaeological evidence. Only last summer archaeologists found several Stone Age settlement sites on the former shores of Lake Kahala (Lang, pers. comm.).

Central Estonia. The Võrtsjärv Lowland is particularly rich in Kunda culture finds (Jaanits et al., 1982). The shoreline of Lake Võrtsjärv was deeply indented during Boreal time. There was an archipelago in the northern part of the lake which provided good opportunities for fishing. The dwelling-sites at Siimusaare, Jälevere, Tamme, Lepakose, Umbusi, and Moksi have been studied by archaeologists (Jaanits et al., 1982; Jaanits, 1992; Figure). Unfortunately, the biostratigraphical material is scattered or absent in the immediate vicinity of the above-mentioned settlement sites. Still, some evidence of landscape disturbance in the area during Mesolithic time may be found on the Ulila pollen diagram (Ilves \& Sarv, 1970). The lower part of the mentioned diagram shows variable and remarkably reduced AP values, a high share of Poaceae pollen, and the start of ruderal communities graph. Simultaneous invasion and rapid expansion of spruce may have been facilitated by forest disturbance in the area between 7000-6200 yr BP, attesting well the archaeological data of the colonization of the Võrtsjärv Lowland during Mesolithic time (Jaanits, 1992). The land uplift and regression of Lake Võrtsjärv led to considerable retreat of the lake shore during the later part of the Mesolithic. Settlers most probably moved to the lowland, closer to food resources, along the contemporary river side and lake shore. Due to rapid paludification of the area, these sites were probably short-lived and soon buried by peat. Therefore peat exploration in the mires of the Võrtsjärv Lowland may uncover several yet unknown Late Mesolithic dwelling-places.

East and Southeast Estonia. The Akali and Kullamäe settlements in the Suur Emajõgi River mouth are well known as Neolithic dwelling-places (Jaanits, 1959; Moora et al., 1988). The charcoal found from the fireplace, now buried by sands at Akali, is dated to $6255 \pm 100 \mathrm{yr}$ BP (Punning et al., 1968). Three pollen diagrams are available from the region. Akali, Saviku, and Kalsa (Figure) bear the traces of the forest disturbance before the elm 
decline. Moreover, the bio- and chronostratigraphical data refer to the existence of the habitation in the area earlier than recorded by archaeologists. The pollen diagram from the Akali settlement site shows a sporadic occurrence of the Artemisia and Chenopodiaceae pollen, which could be interpreted as a weak signal of human activities in the area since the Late Atlantic period (about $6300 \mathrm{yr} \mathrm{BP}$ ), with a precaution that these herbs could have been grown naturally on the sandy beach (Moora et al., 1988). The pollen diagram from Saviku mire (about $1.5 \mathrm{~km} \mathrm{NW}$ of Akali) (Sarv \& Ilves, 1975) supports the hypothesis of the early human interference in the area. An anthropogenic indicator graph starts at $6300 \mathrm{yr}$ BP and contains one Mesolithic (between 6300-5500 yr BP) and several Neolithic vegetation disturbance phases. The Kalsa diagram (about $7 \mathrm{~km}$ NW of Räpina) reflects the same landscape opening up between 6200 5500 yr BP (Kimmel, 1994). The appearance of Pteridium pollen at $6050 \pm 60$ yr BP (TA-1879) may be interpreted as an indicator of some kind of forest grazing, but additional evidence is needed to prove it.

West Estonian Archipelago. During the last decades several new Late Mesolithic settlement sites have been found on Saaremaa Island (Võhma, Kõnnu; Lõugas, 1982) and also on Hiiumaa Island (Kõpu; Lõugas, 1988; Kriiska, 1995, 1996b). The latest biostratigraphical investigations in the vicinity of the ancient settlement sites on Saaremaa: Pelisoo, Surusoo, Jõhvikasoo (near Võhma), Pitkasoo (Naakamäe), and Vedruka (Loona, Kurevere; Figure) have added a great deal of information about human activities during Late Mesolithic and Neolithic times (Saarse \& Königsson, 1992; Poska, 1994; Hansson et al., 1996; Veski, 1996a). New palynological evidence from the region points to the presence of Mesolithic settlers not only in the Võhma, but also in the Käesla (Naakamäe?), and Kihelkonna (Loona?) areas. At Pelisoo and Jõhvikasoo the first signs of the human interference date back to $6500-5300 \mathrm{yr}$ BP. Traces of the forest opening up at the end of the Atlantic, before the major Ulmus decline, occur also on the Pitkasoo diagram and have been interpreted as the Late Mesolithic forest disturbance which led to the formation of some sort of the cultural landscape in the area. Pollen evidence from Kõivasoo mire (Hiiumaa) shows forest disturbance about $6000 \mathrm{yr} \mathrm{BP}$, which is consistent with the latest data from archaeological excavations in the Kõpu area (Kriiska, 1995).

Several diagrams (Tuuljärv, Vaskna in southeastern, Raigastvere, Soitsjärv, and Kuremaa in eastern, and Tondi in northern Estonia; Ilves \& Mäemets, 1987; Pirrus et al., 1987; Moe et al., 1992; Kimmel et al., 1996; Figure) from the areas commonly not associated with the Mesolithic habitation, contain the zones with much the same pattern as described above. They display relatively sharp changes in the amount of the anthropogenic indicators, mainly ruderal communities and fresh meadows, 
and in the number of identified NAP taxa. For example, the Boreal and Early Atlantic part of the Vaskna human impact diagram has similar features with the Boreal part of the Kunda Arusoo diagram. The tree pollen amount has reduced drastically and has become unstable, ruderal communities increase, Poaceae is high. The presence of Cannabis/ Humulus (wild weed) pollen may serve as a proof to the idea expressed by Jaanits (1992) that the fishermen at Tamula used Cannabis and Linum to make nets. The hope of finding Linum pollen is quite weak as it liberates very few pollen grains. On the base of the above-described evidence, three hypotheses may be put forward: (1) there was a settlement site in the environs of Lake Vaskna about 8200-7000 yr BP; (2) the paludification of the lake shore brought about changes in the vegetation and Poaceae pollen mostly originates from the Phragmites communities; (3) both natural and anthropogenic factors are responsible for a drastic increase in herb pollen. To find out, whether this means that the Mesolithic man settled also on the lake shores of the Haanja heights, is the task for the future studies. But if the territory of tribes inhabiting the Pärnu River valley and Võrtsjärv Lowland reached up to Lake Burtnieki (Jaanits, 1992), the Haanja heights may well have served as some sort of the track and camp-site.

\section{NEOLITHIC TIME - FOREST CLEARANCES AND THE FIRST TRACES OF AGRICULTURE}

Up to the end of the Stone Age, the economic activities of man mainly included hunting, fishing, and gathering. So, the indications of human impact traceable on pollen diagrams are rather similar during Mesolithic and Neolithic times. Nevertheless, primitive crop cultivation techniques (such as slash-and-burn agriculture) were introduced to Estonia already during the later part of Neolithic time and settlers started to spread all over the country (Jaanits, 1992). The expansion of the farming led to the introduction of some new plant species (both cultivated and accompanying ones) and needs for cleared land. The appearance of Cerealia pollen is considered the most important evidence of crop cultivation, but commonly there appear several difficulties by the identification of Cerealia pollen. Thus it is possible to rely mostly on data where along Cerealia pollen also some other indicators (peaks of Picea, Pteridium, Isoëtes, charcoal) are present.

North and Northeast Estonia. During Neolithic time major indications of the forest clearance in the area appear on the pollen diagrams between 5000-4500 yr BP. In the Maardu, Saha-Loo, Kahala, and to a lesser extent also in the Kunda area, several indications of the forest disturbance 
(increase in the diversity and amount of the terrestrial light-demanding herbs and NAP as a whole, decrease in Quercetum mixtum (QM) and increase in the charcoal dust amount) are recorded. The second phase of landscape opening up indications, combined already with traces of early crop cultivation, appears at $c$. 4000-3500 yr BP. The earliest finds of cereals in the area are dated to about $3800 \mathrm{yr}$ BP (in the vicinity of Lake Maardu; Veski, 1992). In the biostratigraphical sequence of Kahala mire, along with other human impact indicators, Cerealia and particularly Secale pollen are recorded at about the same time as in Lake Maardu and may probably indicate early land cultivation on alvar soils (Veski \& Lang, 1996; Lang, 1995, 1996). In the Tondi area traces of the forest clearance occur between 4000-3100 yr BP (Lang \& Kimmel, 1996) with a well expressed increase in indicators, characteristic of a landnam phase (Iversen, 1941; Behre, 1988) at c. $3800 \mathrm{yr} \mathrm{BP.}$

Central, East, and Southwest Estonia. Here, like in the above-discussed region, several phases of Neolithic land-use can be distinguished, the earliest of which occurred in most cases around 5000 yr BP. In the Saviku area fresh meadow indicators increase concurrently with an impressive QM decrease between 5200-4700 yr BP. The traces of the forest disturbance are rather well defined also at Ulila site around 5200-5100 yr BP. During the Late Neolithic there seems to have been a stagnation (4500-3800 yr BP) period in colonization and man's influence on the landscape lessened. Graphs of all anthropogenic indicators decreased, AP distinctly recovered from its previous fall, and NAP amount reached its post-Atlantic minimum. This points to the forest regeneration in the area. One possible explanation for those phenomena may be the occurrence of badly drained and heavy clayey or light and relatively pure sandy soils. Here the tillage did not give as good results as in the areas with light calcareous soils and led to a decrease in the colonization rate. Nevertheless, the earliest finds of Cerealia pollen in the region are dated to $4495 \pm 35$ yr BP (Kõrenduse; Pirrus \& Rõuk, 1988; Table 1), thus being older than in northern Estonia. Such distribution of the first cereal findings allows us to suggest that the tillage might have been introduced to Estonia by tribes coming from the southern and south-eastern directions. The arable activity spread then all over the country, but gained importance in economy only in the areas with favourable conditions. It is interesting that one of the most complete archaeological sections of the Estonian Neolithic habitation comes from the Akali dwelling-place, which was situated in an area unfavourable for agriculture now, but was perfect for some kind of prehistoric Hanseatic town (in the mouth of the Suur Emajõgi River). 
The first occurrence of cereals in Estonia

\begin{tabular}{|c|c|c|c|c|c|}
\hline Site & Pollen type & ${ }^{14} \mathrm{C}$ age & Depth, cm & ${ }^{14} \mathrm{C}$ closest date & Depth, cm \\
\hline Lake Kaali & Cerealia & 2420 & 486 & 2500 & 500 \\
\hline \multirow[t]{2}{*}{ Tuiu mire } & Cerealia & 1370 & 65 & $1160 \pm 60$ & $60-65$ \\
\hline & Hordeum $\mathrm{t}$. & 555 & 30 & $1160 \pm 60$ & $60-65$ \\
\hline \multirow[t]{3}{*}{ Lake Maardu } & Avena $\mathrm{t}$. & 3830 & 160 & $4365 \pm 75$ & 190 \\
\hline & Hordeum t. & 2420 & 91 & $2960 \pm 70$ & 111 \\
\hline & Triticum $\mathrm{t}$. & 3830 & 160 & $4365 \pm 75$ & 190 \\
\hline \multirow[t]{3}{*}{ Saha-Loo mire } & Avena $\mathrm{t}$. & 2300 & 80 & $2344 \pm 38$ & $80-83$ \\
\hline & Hordeum $\mathrm{t}$. & 720 & 25 & $2344 \pm 38$ & $80-83$ \\
\hline & Triticum $\mathrm{t}$. & 1725 & 60 & $2344 \pm 38$ & $80-83$ \\
\hline Tondi mire & Cerealia & 2766 & 195 & $2405 \pm 70$ & $170-175$ \\
\hline Lake Raigastvere & Cerealia & 3185 & 630 & $3080 \pm 90$ & 615 \\
\hline Võhma mire & Cerealia & 1550 & 180 & $1580 \pm 50$ & 190 \\
\hline Kalsa mire & Cerealia & 1420 & 146 & $1480 \pm 60$ & $150-155$ \\
\hline Vaskna mire & Cerealia & 1375 & 29 & $1510 \pm 70$ & 30 \\
\hline Lake Tuuljärv & Cerealia & 1985 & 179 & $1670 \pm 70$ & 145 \\
\hline
\end{tabular}

West Estonian Archipelago. The first indications of the Neolithic forest disturbance (abrupt changes in tree curves, increase in the diversity of taxa, amount of light-demanding trees, NAP, and charcoal) in the region appear on the Pitkasoo, Surusoo, and Vedruka pollen diagrams about 5000-4500 yr BP. These traces could be connected with forest clearances in the surroundings of the Neolithic settlement sites at Võhma, Tuiu, Naakamäe, and Loona. Two diagrams (Pitkasoo and Vedruka) with presumably the earliest Cerealia pollen finds in the region are both undated yet. However, it is possible to correlate this biostratigraphical material with the Atlantic/Sub-Boreal transition or with the beginning of the Sub-Boreal chronozone. The Pitkasoo diagram shows distinct changes in the vegetation. The occurrence of Cerealia is accompanied by a Picea sharp peak, a drastic decrease in broad-leaved trees, and an increase in the charcoal particles simultaneously with a significant peak of Plantago lanceolata and terrestrial weeds (Saarse \& Königsson, 1992). Whether the continuous and high charcoal curve marks the start of slash-and-burn agriculture, is hard to decide on the basis of the evidence available.

\section{BRONZE AGE - THE INTRODUCTION AND SPREAD OF CROP GROWING AND CATTLE REARING}

In spite of the fact that the first attempts of tillage were made already during the later part of Neolithic time, we can speak about the start of real 
farming in Estonia only in connection with the Bronze Age Bandkeramik culture (Behre, 1988). During the Bronze Age farming gained importance, overruled fishing and hunting, and became a basis of economy. The Late Bronze farming revolution (Veski \& Lang, 1996) led to drastic changes in land-use and the spread of cultivation from easily tilled alvar soils to other land. Due to the development of agricultural techniques, the habitation moved from coast to inland. The main plant species cultivated during the Bronze Age were: Triticum dicoccum, T. monococcum, Hordeum vulgare, Linum usitatissium, Pisum sativum, Lens esculenta (Behre, 1988). The pattern of pollen curves (an increase in the quantity and diversity of the anthropogenic indicators and decrease in AP) gives good evidence of man's activities and the hypothesis of the gradual deforestation of the landscape corresponds well with the agrarian expansion. In contrast to the Stone Age forest clearances, normally followed by a regeneration of the forest, the clearances in the Bronze Age often caused permanent changes in ecosystems. Most of the Estonian alvars probably started to develop during the Bronze Age.

North Estonia. The imprints of human activities on the environment are traceable in all investigated diagrams (Maardu, Tondi, Kahala, Kunda; Figure). The pattern of the changes is rather similar: a relatively short-term minimum of Corylus is accompanied by a decline of Ulmus and Tilia, often also of Quercus, and an increase in the fresh meadow and ruderate community graphs. Human impact started to intensify at $3500 \mathrm{yr}$ BP (sometimes even earlier), it was at its highest at 3300-3200 yr BP, and declined around $3000 \mathrm{yr}$ BP. A new rise in anthropogenic indicators was registered at $2700 \mathrm{yr} \mathrm{BP}$, when along with other indications the Hordeumtype pollen, followed by Secale cereale, appeared (Veski, 1996b). The last-mentioned species were most probably growing as general ruderate in the crop fields.

Central and South Estonia. Evidences of human activities from central Estonia and the Vorrtsjärv Lowland are concentrated to the time span 3300-3000 yr BP (Raigastvere, Kalsa, Saviku, Ulila, Tuuljärv) expressed by a decrease in QM (mainly Tilia and Ulmus, to some extent also Quercus) and an increase in ruderates, fresh meadow, and grazed forest curves accompanied by the first Cerealia finds at Raigastvere (Pirrus \& Rõuk, 1988). On the Lake Tuuljärv diagram the curve of the cereals starts a little later, at 2500 yr BP (Ilves \& Mäemets, 1987).

West Estonian Archipelago. The traces of Bronze Age man's impact upon the vegetation of Saaremaa Island are quite evident on several investigated pollen diagrams (Kaali, Pelisoo, Surusoo, Vedruka) and the main part of indications (a decrease in QM accompanied by an increase in 
fresh meadows, ruderate communities, and grazed forests indicators) is concentrated to the interval $3200-2800 \mathrm{yr}$ BP.

\section{IRON AGE - A REVOLUTION IN AGRICULTURAL ACTIVITIES}

The Iron Age as a whole was characterized by the well established quickly spreading and developing farming. New advanced techniques enabled people to extend the size and amount of the fields and pastures and to take into use less favourable areas of Estonia. The final revolution in land occupation started in the Late Iron Age about $1100 \mathrm{yr}$ BP.

Traces of human impact upon the vegetation are evident on all investigated diagrams. A distinct rise in the graphs of cultivated land (mainly due to an increase in Secale cereale; Table 2), fresh meadows, and charcoal particles is remarkable. The pattern of the pollen graphs on diagrams points to a large and still increasing amount of unforested and cultivated areas on Estonian territory.

Table 2

The first occurrence of Secale and Centaurea cyanus in Estonia

\begin{tabular}{ll|r|c|c|c}
\hline \multicolumn{1}{c|}{ Site } & Pollen type & ${ }^{14}$ C age & Depth, cm & ${ }^{14}$ C closest date & Depth, cm \\
\hline Tuiu mire & Cecale & 650 & 35 & $1160 \pm 60$ & $60-65$ \\
Lake Maardu & Cecale & 1615 & 61 & $2960 \pm 70$ & 111 \\
& C. cyanus & 780 & 30 & $2960 \pm 70$ & 111 \\
Saha-Loo mire & Cecale & 1295 & 45 & $2344 \pm 38$ & $80-85$ \\
& C. cyanus & 865 & 30 & $2344 \pm 38$ & $80-85$ \\
Tondi mire & C. cyanus & 360 & 20 & $1675 \pm 45$ & $90-95$ \\
Saviku mire & Cecale & 1450 & 85 & $1620 \pm 50$ & 95 \\
& C. cyanus & 1450 & 85 & $1620 \pm 50$ & 95 \\
Võhma mire & C. cyanus & 1760 & 200 & $1580 \pm 50$ & 190 \\
Kalsa mire & C. cyanus & 110 & 36 & $230 \pm 60$ & 75 \\
Vaskna mire & C. cyanus & 795 & 24 & $830 \pm 60$ & 25 \\
Lake Tuuljäry & Cecale & 2450 & 229 & $2600 \pm 80$ & 245 \\
& C. cyanus & 2545 & 239 & $2600 \pm 80$ & 245
\end{tabular}

\section{CONCLUSIONS}

In spite of the relatively high number of sites examined in terms of pollen analysis in Estonia during the last decades, the quality of the determinations and the availability of datings only in few sequences correspond to the level required for the investigation of prehistoric human 
impact. For this reason the material from the West Estonian mainland is not used in discussions. The new high-resolution pollen diagrams from Velise, Kiilaspere, Tõhela, and Ermistu compiled by S. Veski have not yet been published. Still, on the basis of analysed data some outstanding regions and periods in the prehistoric land-use are proposed.

The pollen records show the same Stone Age habitation centres in Estonia as proposed by archaeologists (Jaanits et al., 1982). Regionally they form two belts: one is associated with the North Estonian coast and Saaremaa, and the other extends over central Estonia along the valleys of the Pärnu, Suur Emajõgi, and Navesti rivers and the north coast of Lake Võrtsjärv.

The palynological indications of the Early Mesolithic forest disturbance in the Haanja heights are not supported by the archaeological material. Further investigations are needed in this area to clarify whether these disturbances are natural or man-made.

The prehistoric human activities are of a rather pulsatory character, with stagnations and increases. At about $9000 \mathrm{yr}$ BP there seem to have been woodland disturbances in the coastal zone of the Baltic Sea, on lake shores, and in river valleys of northern and northeastern Estonia. The second period of forest disturbances in northern Estonia and on the Võrtsjärv Lowland occurred at 7000-6500 yr BP, and somewhat later (6500-6000 yr BP) on Hiiumaa and Saaremaa islands and in eastern Estonia. About $5000-4500$ yr BP a relatively well defined period of increase in human impact is traceable almost all over Estonia and the first Cerealia pollen finds are recorded in eastern Estonia (Kõrenduse). At 3800 $\mathrm{yr} \mathrm{BP}$, pollen spectra of several diagrams indicate increasing forest clearance and in some cases also a primitive crop growing (Cerealia and Plantago lanceolata pollen in Lake Maardu; Veski 1996b). About 500 years later (3300-3200 yr BP) indications of extensive forest clearances and arable farming appear in northern Estonia, Võrtsjärv Lowland, and on Saaremaa Island.

The first finds of Secale cereale pollen are known already from $2500 \mathrm{yr}$ BP (Ilves \& Mäemets, 1987), but obviously rye was then growing as weed in other crop fields. The real introduction of Secale cereale is likely to have happened at about $1400-1500 \mathrm{yr}$ BP (Table 2). Still, it is hard to draw any final conclusion before more sites are analysed and dated.

\section{ACKNOWLEDGEMENT}

We would like to express our thanks to U. Miller, A. Raukas, and V. Lang, the leaders of the PACT Project "Environmental History of the Baltic Region", and to colleagues and palynologists K. Kihno, K. Kimmel, H. Mäemets, R. Pirrus, A. Sarv, and S. Veski whose pollen diagrams were 
used to identify the early traces of human impact. Many thanks to A. Kriiska for critical remarks. The current study was sponsored by the Estonian Science Foundation grants Nos 972 and 1958.

\section{REFERENCES}

Behre, K.-E. 1981. The interpretation of anthropogenic indicators in pollen diagrams. Pollen et Spores, 23, 225-245.

Behre, K.-E. 1988. The role of man in European vegetation history. In Vegetation History (Huntley, B. \& Webb, T. III, eds.). Kluwer Academic Publishers, Amsterdam, 633-672.

Berglund, B. E. 1985. Early agriculture in Scandinavia. Norwegian Archaeol. Rev., 18, 77-105.

Berglund, B. E. (ed.). 1991. The Cultural Landscape During the 6000 Years in Southern Sweden. Ecol. Bull., 41.

Berglund, B. E. \& Ralska-Jasiewiczowa, M. 1986. Pollen analyses and pollen diagrams. In Handbook of Holocene Palaeoecology and Palaeohydrology (Berglund, B. E., ed.). John Wiley \& Sons, Chichester, 455-484.

Hackens, T., Hicks, S., Lang, V., Miller, U. \& Saarse, L. (eds.). 1996. Environmental and Cultural History of Coastal Estonia: Recent Advances. PACT, 51 (in press).

Hansson, A. M., Hiie, S., Kihno, K., Masauskaite, R., Moe, D., Seiriene, V. \& Torske, N. A. 1996. A vegetation historical study of Jõhvikasoo, an ombrogeneous mire at Tuiu, Saaremaa, Estonia. In Environmental and Cultural History of Coastal Estonia: Recent Advances (Hackens, T., Hicks, S., Lang, V., Miller, U. \& Saarse, L., eds.). PACT, 51 (in press).

Hicks, S. 1990. Pollen evidence for the activities of man in peripheral areas. Publ. of Karelian Institute, 102, 21-39.

Ilves, E., Liiva, A. \& Punning, J.-M. 1974. Radiocarbon Dating in the Quaternary Geology and Archaeology of Estonia. Acad. Sci. ESSR, Institute of Zoology \& Botany. Institute of Geology. Tallinn (in Russian).

Ilves, E. \& Mäemets, H. 1987. Results of radiocarbon and palynological analyses of coastal deposits of lakes Tuuljärv and Vaskna. In Palaeohydrology of the Temperate Zone III. Mires (Raukas, A. \& Saarse, L., eds.). Valgus, Tallinn, 108-130.

Ilves, E. \& Sarv, A. 1970. Stratigraphie und Chronologie der See- und Torfablagerungen des Moores Ulila (Mittel-Estland). Eesti NSV TA Toim. Keemia. Geol., 19, 2, 135-140 (in Russian).

Indreko, R. 1932. Kiviaja võrgujäänuste leid Narvas. In Eesti Rahva Muuseumi Aastaraamat, VII. Tartu, 48-67.

Iversen, J. 1941. Land occupation in Denmark's Stone Age. Danmarks Geol. Unders., Ser. 2. 66.

Jaanits, L. J. 1959. Siedlungsplätze des Neolithikums und der frühen Metallzeit im Mündungsgebiet des Emajõgi. Acad. Sci. ESSR, Institute of History. Tallinn (in Russian).

Jaanits, L. 1992. Põllumajanduse eelduste kujunemine. In Eesti talurahva ajalugu, 1 (Kahk, J., ed.). Eesti TA Ajaloo Instituut, Tallinn, 42-56.

Jaanits, L., Laul, S., Lõugas, V. \& Tõnisson, E. (eds.). 1982. Eesti esiajalugu. Eesti Raamat, Tallinn.

Kessel, H. \& Punning, J.-M. 1969. Über die Verbreitung und Stratigraphie der Sedimente des Joldiameeres in Estland. Eesti NSV TA Toim. Keemia. Geol., 18, 2, 154-163 (in Russian).

Kimmel, K. 1994. Holotseeni setete stratigraafia ja taimkatte arengu seaduspärasused Peipsi nõo edelaosas. Magistritöö. Eesti TA Geoloogia Instituut, Tallinn (Manuscript).

Kimmel, K., Rajamäe, R. \& Sakson, M. 1996. The Holocene development of Tondi mire, NEstonia: Pollen, diatom and chronological studies. In Environmental and Cultural History of Coastal Estonia: Recent Advances (Hackens, T., Hicks, S., Lang, V., Miller, U. \& Saarse, L., eds.). PACT, 51 (in press).

Kriiska, A. 1995. Archäologische Ausgrabungen auf dem Standort der ehemaligen Steinzeitsiedlung Kõpu I (Ristipõllu). Proc. Estonian Acad. Sci. Humanities and Social Sciences, 44, 4, 410-416.

Kriiska, A. 1996a. Archaeological excavations on the Neolithic site of Riigiküla IV. Proc. Estonian Acad. Sci. Humanities and Social Sciences, 45 (in press). 
Kriiska, A. 1996b. Archaeological studies on the Kõpu Peninsula. Proc. Estonian Acad. Sci. Humanities and Social Sciences, 45 (in press).

Kriiska, A. 1996c. Stone Age settlements in the lower reaches of the Narva River, North-Eastern Estonia. In Environmental and Cultural History of Coastal Estonia: Recent Advances (Hackens, T., Hicks, S., Lang, V., Miller, U. \& Saarse, L., eds.). PACT, 51 (in press).

Lang, V. 1995. Prehistoric and medieval field systems in Estonia. In Tools \& Tillage (Lerche, G., Fenton, A. \& Steensberg, A., eds.). National Museum of Denmark, Copenhagen, VII: 2-3 1993-1994, 67-82.

Lang, V. 1996. Archaeological evidence for human settlement near the Tondi Mire, North Estonia. In Environmental and Cultural History of Coastal Estonia: Recent Advances (Hackens, T., Hicks, S., Lang, V., Miller, U. \& Saarse, L., eds.). PACT, 51 (in press).

Lang, V. \& Kimmel, K. 1996. Archaeological and palynological evidence for human impact on the vegetation of the Tondi area, North Estonia. In Environmental and Cultural History of Coastal Estonia: Recent Advances (Hackens, T., Hicks, S., Lang, V., Miller, U. \& Saarse, L., eds.). $P A C T, 51$ (in press).

Lepland, A., Hang, T., Kihno, K., Sakson, M., Sandgren, P. \& Lepland, A. 1996. Holocene sea-level changes and environmental history in the Narva area, North-eastern Estonia. In Environmental and Cultural History of Coastal Estonia: Recent Advances (Hackens, T., Hicks, S., Lang, V., Miller, U. \& Saarse, L., eds.). PACT, 51 (in press).

Lõugas, V. 1982. Täiendusi Hiiumaa muinasajaloole. Nõukogude Hiiumaa, 93, 6. ja 11. aug.

Lõugas, V. 1988. Steingräberfeld in Võhma (Insel Saaremaa). Proc. Acad. Sci. ESSR. Social Sciences, 37, 4, 348-351 (in Russian).

Lõugas, V. 1992. Põllumajanduse kujunemine majanduse aluseks. In Eesti talurahva ajalugu, 1 (Kahk, J., ed.). Eesti TA Ajaloo Instituut, Tallinn, 57-75.

Moe, D., Kihno, K. \& Pirrus, R. 1992. Anthropogenic disturbance of vegetation in Estonia through the Holocene based on some selected pollen diagrams. A preliminary survey. In Estonia: Nature, Man and Cultural Heritage (Hackens, T., Lang,V. \& Miller, U., eds.). PACT, 37, 79-95.

Moora, T., Ilomets, M. \& Jaanits, L. 1988. Muistsetest loodusoludest Akali kiviaja asulakoha lähiümbruses. In Loodusteaduslikke meetodeid Eesti arheoloogias (Rõuk, A.-M. \& Selirand, J. , eds.). Eesti TA Ajaloo Instituut, Tallinn, 26-38.

Pirrus, R. \& Rõuk, A.-M. 1988. Inimtegevuse kajastumisest Vooremaa soo- ja järvesetetes. In Loodusteaduslikke meetodeid Eesti arheoloogias (Rõuk, A.-M. \& Selirand, J., eds.). Eesti TA Ajaloo Instituut, Tallinn, 39-53.

Pirrus, R., Rõuk, A. \& Liiva, A. 1987. Geology and stratigraphy of the reference site of Lake Raigastvere in Saadjärv drumlin field. In Palaeohydrology of the Temperate Zone II. Lakes (Raukas, A. \& Saarse, L., eds.). Valgus, Tallinn, 101-122.

Poska, A. 1994. Three Pollen Diagrams From Coastal Estonia. Licentiate Thesis. Kvartärgeologiska Avdelningen, Uppsala Universitet, 170. Uppsala-Tallinn.

Poska, A. \& Königsson, L.-K. 1996. Traces of Mesolithic land-use in a pollen diagram from the Kunda Arusoo mire at Kunda. In Environmental and Cultural History of Coastal Estonia: Recent Advances (Hackens, T., Hicks, S., Lang, V., Miller, U. \& Saarse, L., eds.). PACT, 51 (in press).

Punning, J.-M., Liiva, A. \& Ilves, E. 1968. Verzeichnis der im Institut für Zoologie und Botanik der Akademie der Wissenschaften der Estnischen SSR Mittels der Radiokohlenstoff-Methode Datierten Proben. III. Proc. Acad. Sci. ESSR. Biology, 17, 4, 426-430 (in Russian).

Saarse, L. \& Königsson, L.-K. 1992. Holocene Environmental changes on the Island of Saaremaa. In Estonia: Nature, Man and Cultural Heritage (Hackens, T., Lang,V. \& Miller, U., eds.). PACT, 37, 97-131.

Saarse, L., Rajamäe, R., Heinsalu, A. \& Vassiljev, J. 1991. The biostratigraphy of sediments deposited in the Lake Kaali Meteorite Impact structure, Saaremaa Island, Estonia. Bull. Geol. Soc. Finland, 63, 2, 129-139.

Sarv, A. \& Ilves, E. 1975. Über das Alter der Holozänen Ablagerungen im Mündungsgebiet des Flusses Emajõgi (Saviku). Eesti NSV TA Toim. Keemia. Geol., 24, 1, $64-69$ (in Russian).

Veski, S. 1992. The Holocene Development of Lake Maardu and the Vegetational History of North Estonia. Licentiate Thesis. Kvartärgeologiska Avdelningen, Uppsala Universitet, 165. Uppsala. 
Veski, S. 1996a. A contribution to the history of vegetation and human impact in northern Saaremaa, Estonia, based on the biostratigraphy of the Surusoo mire: preliminary results. In Environmental and Cultural History of Coastal Estonia: Recent Advances (Hackens, T., Hicks, S., Lang, V., Miller, U. \& Saarse, L., eds.). PACT, 51 (in press).

Veski, S. 1996b. Vegetational history of Lake Maardu sediments based on the pollen stratigraphy. In Environmental and Cultural History of Coastal Estonia: Recent Advances (Hackens, T., Hicks, S., Lang, V., Miller, U. \& Saarse, L., eds.). PACT, 51 (in press).

Veski, S. \& Lang, V. 1996. Prehistoric human impact in the vicinity of Lake Maardu, North Estonia. A synthesis of pollen analytical and archaeological results. In Environmental and Cultural History of Coastal Estonia: Recent Advances (Hackens, T., Hicks, S., Lang, V., Miller, U. \& Saarse, L., eds.). PACT, 51 (in press).

\title{
ÜLEVAADE EELAJALOOLISE INIMESE MÕJUST EESTI KESKKONNALE ÕIETOLMU ANALÜÜSIDE PÕHJAL
}

\author{
Anneli POSKA, Leili SAARSE
}

30 õietolmudiagrammi põhjal on koostatud uued $\mathrm{nn}$. inimmõju diagrammid selgitamaks, mis ajal ja mis ulatuses on jälgitavad antropogeensed muutused metsade koosseisus. Biostratigraafiline materjal näitab, et mesoliitilised asustuskolded paiknesid kahe lääne-ida-suunalise vööndina. Esimene neist järgis rannajoont, teine kulges läbi Kesk-Eesti, mööda suuremate jõgede orge ja Võrtsjärve põhjakallast. Esimesed märgid inimese tegevusest rannikualal ulatuvad juba preboreaali ja boreaali piirile. Alates 5000 a.t. on inimmõju kajastusi õietolmuspektrites leida juba kõikjal üle Eesti. Esimesed kindlad viited maaviljeluse tekkele pärinevad Maardu ümbrusest 3800 a.t. Rukkikasvatus algas meil u. 14001500 a.t.

\section{ОБЗОР АНТРОПОГЕННОГО ВЛИЯНИЯ НА ИЗМЕНЕНИЕ ОКРУЖАЮЩЕЙ СРЕДЫ В ЭСТОНИИ ПО ДАННЫМ СПОРОВО- ПЫЛЬЦЕВЫХ ДИАГРАММ}

Аннели ПОСКА, Лейли СААРСЕ

По результатам анализа 30 спорово-пыльцевых диаграмм, отобразивших характер воздействия человека на изменение лесного покрова в Эстонии, были составлены т. н. диаграммы антропогенного влияния. Биостратиграфический материал показал, что первые стоянки человека на территории Эстонии возникли в мезолите. Они располагались по двум линиям западно-восточного направления: по 
берегу моря и в долинах рек Пярну, Навести, Суур-Эмайыги и по северному берегу оз. Выртсъярв. Первые признаки деятельности человека в этих местах прослеживаются уже на границе пребореала/ бореала. Взаимодействие человеческого общества-и природы на территории Эстонии началось около 5000 лет т. н. Первые сведения о земледельческой деятельности в окрестностях Маарду датируются временем 3800 лет т. н., начало возделывания ржи - периодом 14001500 лет т. н. 